Provided for non-commercial research and education use. Not for reproduction, distribution or commercial use.

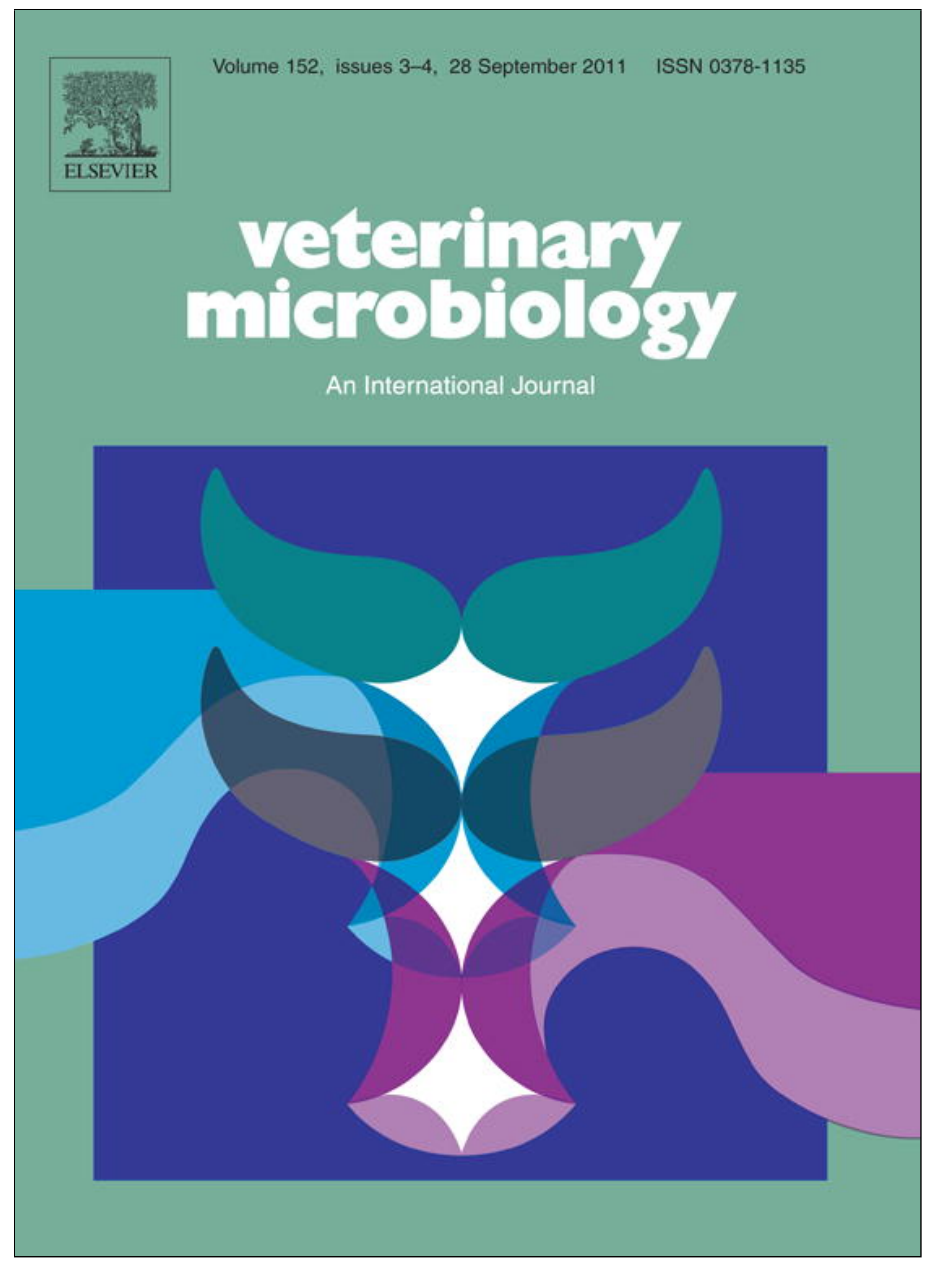

This article appeared in a journal published by Elsevier. The attached copy is furnished to the author for internal non-commercial research and education use, including for instruction at the authors institution and sharing with colleagues.

Other uses, including reproduction and distribution, or selling or licensing copies, or posting to personal, institutional or third party websites are prohibited.

In most cases authors are permitted to post their version of the article (e.g. in Word or Tex form) to their personal website or institutional repository. Authors requiring further information regarding Elsevier's archiving and manuscript policies are encouraged to visit:

http://www.elsevier.com/copyright 
Short Communication

\title{
Serological evidence of West Nile virus circulation in Portugal
}

\author{
Sílvia C. Barros, Fernanda Ramos, Teresa Fagulha, Margarida Duarte, Margarida Henriques, \\ Tiago Luís, Miguel Fevereiro* \\ Laboratório Nacional de Investigação Veterinária, Virologia, Estrada de Benfica 701, 1500-011 Lisboa, Portugal
}

\section{A R T I C L E I N F O}

\section{Article history:}

Received 4 March 2011

Received in revised form 26 April 2011

Accepted 6 May 2011

Keywords:

Flavivirus

West Nile virus

WNV

Serosurvey

\begin{abstract}
A B S T R A C T
The circulation of West Nile virus in Portugal was assessed by serological surveys conducted during 2004-2010 in horses and birds. The detection of WNV antibodies in both species in all the years covered by the study as well as the presence of anti-WNV IgM in symptomatic horses that had not traveled outside the country, support the notion that WNV circulates in Portugal.
\end{abstract}

() 2011 Elsevier B.V. All rights reserved.

\section{Introduction}

West Nile virus (WNV) is a vector-borne flavivirus that is transmitted in an enzootic cycle between birds and by mosquitoes; incidental transmission to humans and horses occurs during periods of intense viral amplification (Castillo-Olivares and Wood, 2004). Mosquitoes of the genus Culex are the main vectors of WNV. Although most infections are benign, about $20 \%$ of infected persons have fever, rash, arthralgia, and myalgia, and 1\% of these may develop severe disease, including meningoencephalitis, encephalitis, and polio-like flaccid paralysis (Hayes et al., 2005 ). In horses, $20 \%$ of infections result in clinical disease, of which about $90 \%$ involve neurologic symptoms with ataxia, weakness, recumbency, muscle fasciculation, and high death rates (30\%) (Castillo-Olivares and Wood, 2004).

Birds have been implicated in spreading WNV during migratory events in Europe, Asia, Africa, and the Middle East. In the Mediterranean basin, outbreaks of WNV infection in recent years have been reported in France (2004 and 2006), Italy (2008, 2009), Morocco (2010), Spain

\footnotetext{
* Corresponding author. Tel.: +351 217115288; fax: +351 217115387. E-mail address: miguel.fevereiro@lniv.min-agricultura.pt
} (M. Fevereiro).
(2010) (www.oie.int/wahis/public.php?page=home) and Greece (Papa et al., 2010). In Portugal, the first evidence of WNV circulation was documented in 1971 when the virus was isolated (Filipe and de Andrade, 1990). Later on, a serological survey conducted from 1999 to 2002 revealed $12 \%$ and $3 \%$ positivity, respectively in birds and horses (Formosinho et al., 2006). In the summer 2004, two human cases of WNV infection were reported in tourists in the Algarve region (Connell et al., 2004), after which WNV was detected in mosquitoes collected in the same region (Esteves et al., 2004).

Here we report the results of a serological and virological survey of horses and birds during 2004-2010.

\section{Methods and results}

As a result of the reported cases of WNV in humans in Algarve (2004), a WNV monitoring program was established by the national veterinarian authorities based on serological survey in birds and horses.

During 2004-2010 serum samples from horses ( $n=1313)$, wild birds $(n=52)$ and birds from zoological parks $(n=64)$ were examined for WNV immunoglobulin G (IgG) by using a commercial ELISA (competition ELISA kit, ID-VET, Montepellier, France). Due to the cross-reactivity with other Flavivirus, ELISA-positive serum samples were 
further tested for neutralizing antibodies using a micro virus-neutralization test (VNT). Only samples that were positive in both tests were considered positive. Briefly, replicates of twofold dilutions of heat inactivated serum samples were incubated with a constant amount (100 $\mathrm{TCID}_{50}$ ) of WNV-Eg101 strain, at $37{ }^{\circ} \mathrm{C}-5 \% \mathrm{CO}_{2}$, for $1 \mathrm{~h}$ in 96-well microplates. Then Vero E6 cells were added to each well and the plates were further incubated for 4 days. A serum dilution is considered to be positive if there is a $100 \%$ reduction in viral cytophatic effect. End-points of serum replicates where then calculated using the Spearman-Kärber method (Karber, 1931). Only samples that showed neutralization at dilutions $\geq 1$ :10 were considered positive. Controls for cytotoxicity in the absence of virus were included for every sample at a dilution of $1: 10$. Horse serum samples were also tested for WNV IgM (ELISA IgM antibody kit, IDEXX, Montepellier, France). Infection was considered recent when IgMs against WNV were present.

To detect viral genome, horse blood and oropharyngeal or cloacal swab samples, collected from different bird species that routinely came for diagnosis of Avian Influenza viruses, were used. Total RNA was extracted from samples by using a nucleic acid extraction workstation BioSprint 96 (Qiagen), according to manufacturer's instructions. Samples were screened for WNV RNA by real time RT-PCR (rRT-PCR) according to Lanciotti et al. (2000).

Of the 116 birds studied, 23 (19.8\%) had antibodies to WNV (Table 1) with neutralization titers ranging from 20 to 40. Seropositivity was detected in eagles, owls, storks, flamingos, ostriches, rheas and ibis, all healthy at the time of sampling.

In horses, 40 (3\%) of 1313 serum samples were positive for WNV neutralizing antibodies with titers that ranged from 16 to 2560. Although most samples were collected from apparently healthy animals, two of seven seropositive horses sampled in October-November 2010, showed neurological signs compatible with WNV infection. These animals belonged to the same farm in the district of Setúbal (Fig. 1) and both tested positive for IgM antibodies indicating a recent contact with WNV. One of the horses died and was buried before a second blood sample or CNS tissue could be taken, while the other horse recovered and seroconvert. Serum samples from the latter animal, collected 15 days apart showed a thirty-two fold increase in neutralizing antibody titers, with IgM antibodies decreasing from positive to borderline values in the IgM-ELISA. Blood samples of these two horses as well as all other samples from horses $(n=551)$ and birds $(n=860)$ received during this study were WNV RT-PCR negative.

\section{Discussion}

Our study provides evidence that WNV circulates in Portugal, at least since 2004 at a low endemic prevalence. Neutralizing antibodies against WNV were detected in 23 out of 116 and 40 out of 1313 samples. Bird samples were from wild non-migrating and from residential free living birds belonging to zoo farms, suggesting that WNV infection occurred locally.

During the summer of 2004, two human cases were reported in tourists in Ria Formosa (Algarve), a marshland that shelters resident and migratory wild birds that is infested by mosquitoes in the summer (Almeida et al., 2010). Shortly after this report, a serological survey in horses and birds from neighboring areas were performed. Nine horses and two birds showed neutralizing antibodies for $\mathrm{WNV}$, although no disease or deaths were reported in these species.

In July 2010, a new suspected case of WNV infection of a woman resident in the district of Setúbal, which is located approximately $40 \mathrm{~km}$ south of Lisbon, triggered a WNV survey in horses living in the same area. Neutralizing antibodies were detected in seven horses of which two were also anti-WNV IgM positive, indicating a recent infection. In fact, seroconversion was observed in one of them and by the time samples were collected WNV was already undetectable in blood by RT-PCR. However, it is important to note that samples were collected after the onset of neurological signs, when virus is unlikely to be present in blood due to short duration of viraemia (Castillo-Olivares and Wood, 2004). The two cases were identified in late summer and notified to OIE (http:// www.oie.int/wahis/public.php?page=single_report\&pop= 1\&reportid=9879 and http://www.oie.int/wahis/public.

Table 1

Summary of Portuguese WNV surveillance during 2004-2010.

\begin{tabular}{|c|c|c|c|c|c|c|c|c|c|c|}
\hline \multirow[t]{3}{*}{ Year } & \multirow{2}{*}{\multicolumn{3}{|c|}{$\begin{array}{l}\text { Birds } \\
\text { Serology }\end{array}$}} & & & \multicolumn{5}{|l|}{ Horses } \\
\hline & & & & \multicolumn{2}{|l|}{ rRT-PCR } & \multicolumn{3}{|c|}{ Serology } & \multicolumn{2}{|l|}{ rRT-PCR } \\
\hline & No. tested & $\begin{array}{l}\text { ELISA } \\
\text { positive }\end{array}$ & $\begin{array}{l}\text { Confirmed } \\
\text { by VNT }\end{array}$ & No. tested & Positive & $\begin{array}{l}\text { No. } \\
\text { tested }\end{array}$ & $\begin{array}{l}\text { ELISA } \\
\text { positive }\end{array}$ & $\begin{array}{l}\text { Confirmed } \\
\text { by VNT }\end{array}$ & No. tested & Positive \\
\hline 2004 & 24 & ND & 2 & ND & 1 & 167 & ND & 9 & ND & 1 \\
\hline 2005 & 16 & ND & 7 & ND & 1 & 131 & ND & 7 & ND & I \\
\hline 2006 & 64 & 12 & 12 & 391 & 0 & 39 & 0 & I & 9 & 0 \\
\hline 2007 & 0 & 1 & 1 & 16 & 0 & 105 & 10 & 7 & 6 & 0 \\
\hline 2008 & 0 & 1 & 1 & 0 & 1 & 155 & 8 & 8 & 27 & 0 \\
\hline 2009 & 1 & 1 & 1 & 197 & 0 & 162 & 4 & 2 & 18 & 0 \\
\hline 2010 & 11 & 1 & 1 & 256 & 0 & 554 & $24\left(2^{*}\right)$ & 7 & 491 & 0 \\
\hline Total & 116 & 14 & 23 & 860 & 0 & 1313 & 46 & 40 & 551 & 0 \\
\hline
\end{tabular}

VNT: virus neutralization test; ND: not determined.

ELISA IgM positive results. 
A

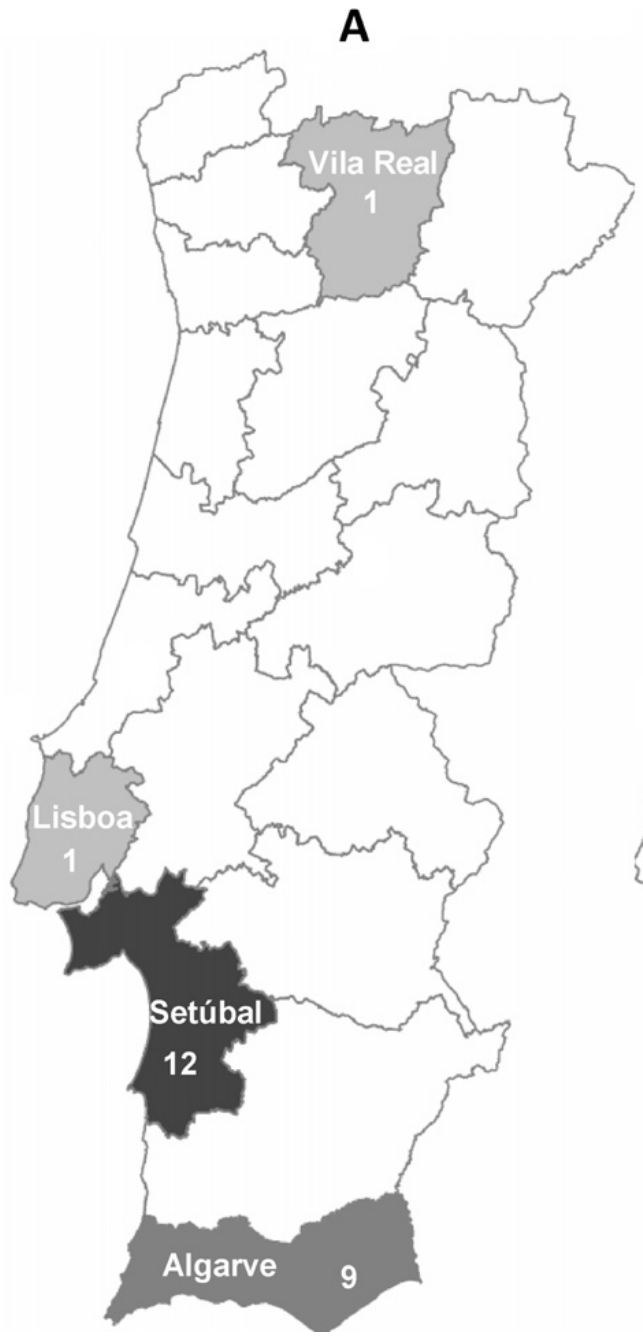

B

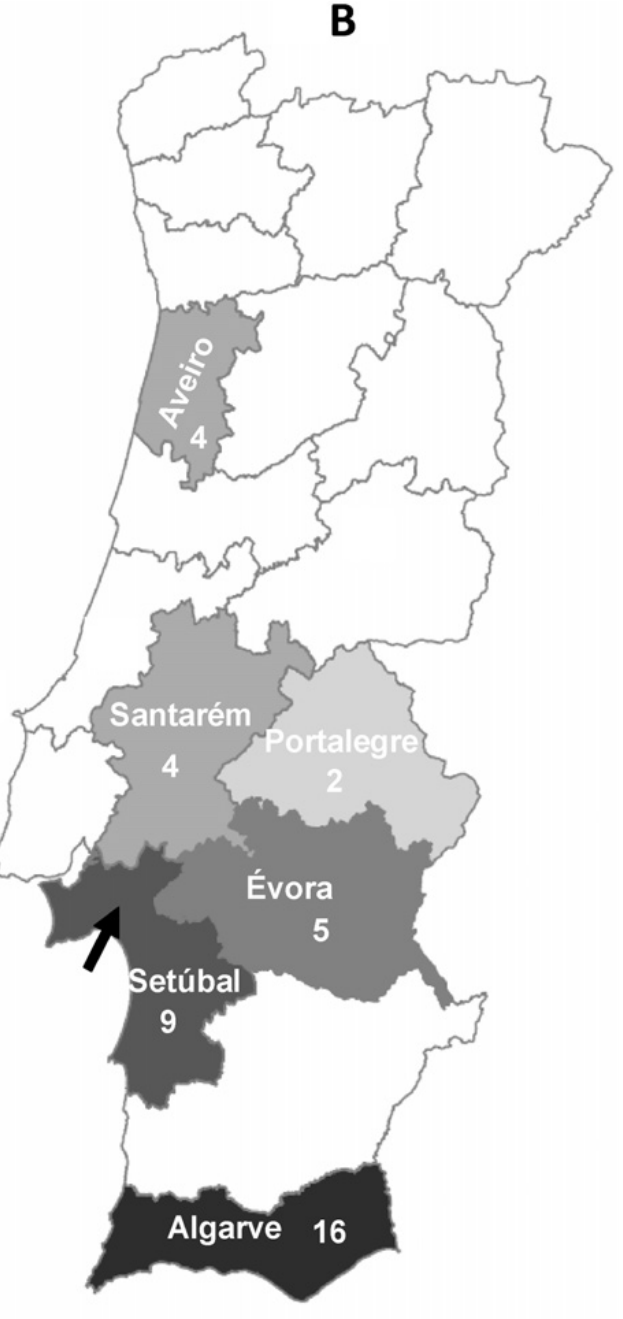

Fig. 1. Geographic distribution of WNV positive serology in birds (A) and horses (B), Portugal, 2004-2010. The number of positive samples per district is indicated. The location of the farm where the two cases of WNV reported to OIE (2010) occurred is indicated by an arrow.

php?page=single_report\&pop=1\&reportid=10066). Since these animals had not traveled outside this region, the results confirm the presence of WNV in the district of Setúbal where a wetland located in the estuary of the river Sado, serves as natural wild bird sanctuary. This area has mosquitoes-rich habitats which activity and density peak in summer, favoring the maintenance of WNV life cycle. Serum samples were not available from local birds but no abnormal bird deaths were observed.

It is possible that WNV had been introduced by migratory birds and then amplified in local bird populations as described in other countries (Zeller and Schuffenecker, 2004; Schuffenecker et al., 2005; Figuerola et al., 2007; Gangoso et al., 2010). Formal evidence for introduction of WNV in the country by migratory birds will require a search for acute infection during migration.

Portugal has ecological conditions for WNV re-emergence as there are several wetlands that act as bird sanctuaries and also because of its location on the most western migratory bird route between Africa and Europe (Almeida et al., 2010).

Cross-reactivity among flaviviruses has been a great diagnostic challenge, especially for members of the
Japanese encephalitis virus (JEV) serocomplex, which includes WNV. It is difficult to differentiate between the strains by using ELISA (Koraka et al., 2002). However the use of virus neutralization assay minimizes the crossreactivity between flaviviruses. Also virus isolation and/or detection of viral RNA by RT-PCR can be the method of choice during the acute phase of infection (Koraka et al., 2002).

Limitations of this study concerns with the type of samples analyzed. Oropharyngeal or cloacal swabs from birds may not be the ideal samples for WNV detection (Johnson et al., 2010) and the number of bird serum samples available for testing was limited, particularly from district of Setúbal, where the two WNV-IgM positive horses were detected. Also the rRT-PCR (Lanciotti et al., 2000) used in this study may not detect all WNV lineage 2. However, the 747 samples collected during 2010 tested negative with a more robust rRT-PCR developed in our laboratory (unpublished). According to a proficiency test conducted recently by the European reference laboratory for WNV (ANSES-de Santé Animale Maisons-Alfort, France), the primers pair and probe used with this new protocol can detect strains of lineages 1 and 2 of WNV. 
The nonspecific clinical signs combined with the unfamiliarity of veterinarians with WNV infection, suggest that the infection could easily be under diagnosed. Except for fever, clinical signs of WNV in horses are almost exclusively of neurological nature and reflect the pathology of central nervous system. Our results illustrate the need of implementation of a sentinel surveillance program for WNV. From a public health perspective, serosurveys of wild birds, mosquitoes and horses may serve as an early warning system for WNV outbreaks among humans. As previously reported (Castillo-Olivares and Wood, 2004), our data points horses as good sentinels for WNV infection surveillance.

\section{Conflicts of interest}

None.

\section{Acknowledgments}

We thank Arminda Batista e Ana Almeida for excellent technical support. We are also grateful to Drs. Rui Mendes and Vanessa Soeiro for collecting horse and bird samples. We are thankful to Fundação para a Ciência e a Tecnologia (FCT) for Contrato-Programa "Ciência 2008" to Sílvia C. Barros.

\section{References}

Almeida, A.P., Freitas, F., Novo, M.T., Sousa, C.A., Rodrigues, J.C., Alves, R., Esteves, A., 2010. Mosquito surveys and West Nile virus screening in two different areas of Southern Portugal, 2004-2007. Vector Borne Zoonotic Dis. 10, 673-680.

Castillo-Olivares, J., Wood, J., 2004. West Nile virus infection of horses. Vet. Res. 35, 467-483.

Connell, J., McKeown, P., Garvey, P., Cotter, S., Conway, A., O'Flanagan, D., O'Herlihy, B.P., Morgan, D., Nicoll, A., Lloyd, G., 2004. Two linked cases of West Nile virus (WNV) acquired by Irish tourists in the Algarve, Portugal. Euro Surveill. 8, 2517.

Esteves, A., Almeida, A.P., Galao, R.P., Parreira, R., Piedade, J., Rodrigues, J.C., Sousa, C.A., Novo, M.T., 2004. West Nile virus in southern Portugal. Vector Borne Zoonotic Dis. 5, 410-413.

Figuerola, J., Soringuer, R., Rojo, G., Tejedor, C.G., Jimenez-Clavero, M.A. 2007. Seroconversion in wild birds and local circulation of West Nile virus, Spain. Emerg. Infect. Dis. 13, 1915-1917.

Filipe, A.R., de Andrade, H.R., 1990. Arboviruses in the Iberian Peninsula. Acta Virol. 34, 582-591.

Formosinho, P., Santos-Silva, M.M., Santos, A., Melo, P., Encarnação, V., Santos, N., Nunes, T., Agrícola, R., Portas, M., 2006. O virus West Nile em Portugal-estudos de vigilância epidemiológica. (Portuguese) Ver. Port. Cienc. Vet. 101, 551-558.

Gangoso, L., Grande, J.M., Llorente, F., Jiménez-Clavero, M.A., Pérez, J.M., Figuerola, J., 2010. Prevalence of neutralizing antibodies to West Nile virus in Eleonora's Falcons in the Canary Islands. J. Wildl. Dis. 46, $1321-1324$.

Hayes, E.B., Sevjar, J.J., Zaki, S.R., Lanciotti, R.S., Bode, A.V., Campbell, G.L., 2005. Virology, pathology, and clinical manifestations of West Nile virus disease. Emerg. Infect. Dis. 11, 1174-1179.

Johnson, G, Nemeth, N., Hale, K., Lindsey, N., Panella, N., Komar, N., 2010. Surveillance for West Nile Virus in American White Pelicans, Montana, USA, 2006-2007. Emerg. Infect. Dis. 16, 406-411.

Karber, G., 1931. Beitrag zur kollektiven Behandlung pharmakologischer Reihenversuche. Path. u. Pharmakol. 162, 480-483.

Koraka, P., Zeller, H., Niedrig, M., Osterhaus, A., Groen, J., 2002. Reactivity of serum samples from patients with a flavivirus infection measured by immunofluorescence assay and ELISA. Microb. Infect. 4, 12091215.

Lanciotti, R.S., Kerst, A.J., Nasci, R.S., Godsey, M.S., Mitchell, C.L., Savage, H.M., Komar, N., Panella, N.A., Allen, B.C., Volpe, K.E., Davis, B.S., Roehrig, J.T., 2000. Rapid detection of West Nile virus from human clinical specimens, field-collected mosquitoes, and avian samples by a TaqMan reverse transcriptase-PCR assay. J. Clin. Microbiol. 38, 4066-4071.

Papa, A, Danis, K, Baka, A, Bakas, A, Dougas, G, Lytras, T, Theocharapoulos, G., Chrysagis, D., Vassiliadou, E., Kamaria, F., Liona, A., Mellou, K., Saroglou, G., Panagiotopoulos, T., 2010. Ongoing outbreak of West Nile virus infections in humans in Greece. Euro Surveillance 15 (34).

Schuffenecker, I., Peyrefitte, C.N., Harrak, M., Murri, S., Leblond, A., Zeller, H.G., 2005. West Nile virus in Morocco, 2003. Emerg. Infect. Dis. 11 306-309.

Zeller, H.G., Schuffenecker, I., 2004. West Nile: an overview of its spread in Europe and the Mediterranean Basin in contrast to its spread in the Americas. Eur. J. Clin. Microbiol. Infect. Dis. 23, 147-156. 